UNES Journal of Education Scienties
Volume 2, Issue 1, May 2018
P-ISSN 2598-4985
E-ISSN 2598-4993
Open Access at: http://lppm.ojs.unespadang.ac.id/index.php/UJES

\title{
PENGEMBANGAN MEDIA PEMBELAJARAN BERBASIS MULTIMEDIA INTERAKTIF PADA MATA KULIAH KERITING DAN CAT RAMBUT MAHASISWA JURUSAN TATA RIAS DAN KECANTIKAN FPP UNIVERSITAS NEGERI PADANG
}

\section{LEARNING MEDIA DEVELOPMENT BASED INTERACTIVE MULTIMEDIA IN CURRENT LEVEL AND CAT HAIR STUDENTS STUDENTS MAJOR AND MAJOR PROGRAMS FPP UNIVERSITY OF PADANG}

\author{
Murni Astuti ${ }^{1}$, Ika Parma Dewi ${ }^{2}$, Rahmiati ${ }^{3}$, Tyas Asih Surya Mentari ${ }^{4}$ \\ 1,2,3,4Universitas Negeri Padang. E-mail: murni.astuti937@gmail.com
}

Submitted: 19-11-2017, Reviewed: 25-03-2018, Accepted: 31-05-2018

http://lppm.ojs.unespadang.ac.id/index.php/UJES

\begin{tabular}{|c|c|}
\hline INFO ARTIKEL & ABSTRAK \\
\hline $\begin{array}{l}\text { Kata kunci: } \\
\text { pembelajaran, tata } \\
\text { keriting, cat rambut, } \\
\text { multimedia, interaktif } \\
\text { hal: } 1-9\end{array}$ & $\begin{array}{l}\text { Pembelajaran Tata Keriting dan Cat Rambut merupakan salah satu } \\
\text { mata kuliah wajib di Jurusan Tata Rias dan Kecantikan Universitas } \\
\text { Negeri Padang, diikuti oleh mahasiswa semester } 3 \text { dengan bobot } 3 \\
\text { SKS terdiri dari } 1 \text { teori dan } 2 \text { praktek. Materi konsep dasar keriting } \\
\text { desain dan teknik keriting desain sulit dipahami dan diaplikasikan. } \\
\text { Berdasarkan pemikiran tersebut diperlukan media pembelajaran yang } \\
\text { tepat dan menarik untuk membantu mahasiswa belajar. Penelitian ini } \\
\text { menggunakan metode penelitian dan pengembangan (Research and } \\
\text { Development/R\&D). Model pengembangan multimedia interaktif ini } \\
\text { menggunakan model IDI (Instruksional Development Institute). Model } \\
\text { IDI menetapkan prinsip-prinsip pendekatan sistem yang meliputi tiga } \\
\text { tahap yaitu define, develop, dan evaluate. Subjek penelitian dalam } \\
\text { pengembangan multimedia interaktif ini adalah mahasiswa seksi } \\
\text { 201710780017 dan dosen mata kuliah keriting dan cat rambut Jurusan } \\
\text { Tata Rias dan Kecantikan FPP Universitas Negeri Padang. Validasi } \\
\text { media pada mata kuliah Keriting dan Cat Rambut telah dinilai oleh } \\
\text { validator dari berbagai kajian dengan kriteria Materi dan } \\
\text { bentuk/desain media dengan kategori "sangat valid". Kepraktisan } \\
\text { media dalam pembelajaran dapat dilihat dari keterlaksanaan } \\
\text { penggunaan media pembelajaran secara keseluruhan dengan baik. Ini } \\
\text { terlihat dari hasil respon dosen/praktisi yang memperoleh persentase } \\
\text { rata-rata 90,63\%, dan hasil respon mahasiswa yang memperoleh } \\
\text { persentase rata-rata 88,17\%. Hal ini menunjukkan media pembelajaran } \\
\text { yang dikembangkan termasuk pada kategori "sangat praktis". } \\
\text { Efektivitas media yang dikembangkan terhadap mahasiswa dilihat } \\
\text { dari Hasil belajar mahasiswa setelah pembelajaran dengan } \\
\text { menggunakan Multimedia Interaktif. Jumlah mahasiswa yang } \\
\text { mencapai nilai tuntas sebanyak } 75 \% \text {, dengan nilai rata-rata mahasiswa } \\
86,2 \text { Hal ini menunjukan bahwa efektifitas pembelajaran dari segi } \\
\text { hasil belajar adalah "sangat efektif". }\end{array}$ \\
\hline
\end{tabular}




\begin{tabular}{|c|c|}
\hline ARTICLE INFO & ABSTRACT \\
\hline $\begin{array}{l}\text { Keywords: } \\
\text { learning, curling, hair } \\
\text { dye, multimedia, } \\
\text { interactive } \\
\text { page: } 1 \text { - } 9\end{array}$ & $\begin{array}{l}\text { Curly and Hair Paint Learning is one of the compulsory subjects in } \\
\text { the Department of Makeup and Beauty of State University of } \\
\text { Padang, followed by 3rd semester students with } 3 \text { credits weight } \\
\text { consisting of } 1 \text { theory and } 2 \text { practice. Based on the observation of the } \\
\text { material the basic concept of curly design and curly design } \\
\text { techniques is difficult to understand and apply. Based on these } \\
\text { thoughts required appropriate and interesting learning media to help } \\
\text { students learn. This research uses research and development (R E D) } \\
\text { method. This interactive multimedia development model uses IDI } \\
\text { model (Instructional Development Institute). The IDI model } \\
\text { establishes the principles of a system approach that includes three } \\
\text { stages of define, develop, and evaluate. Research subjects in the } \\
\text { development of interactive multimedia is a sexy student } \\
\text { 201710780017 and lecturer curly and hair dye courses Department } \\
\text { of Makeup and Beauty FPP State University of Padang. Media } \\
\text { validation on Kinks and Paint courses has been assessed by validators } \\
\text { from various studies with material criteria and forms/media designs } \\
\text { under the category of "highly valid". Practical media in learning can } \\
\text { be seen from the implementation of the use of learning media as a } \\
\text { whole well. This is seen from the response of lecturers / practitioners } \\
\text { who get an average percentage of 90.63\%, and the results of student } \\
\text { responses who get an average percentage of 88.17\%. This shows that } \\
\text { the developed learning media belongs to the "very practical" } \\
\text { category. The effectiveness of the media developed against students is } \\
\text { seen from the students learning outcomes after learning using } \\
\text { Interactive Multimedia. The number of students who reached the } \\
\text { total value of } 75 \% \text { with an average score of 86.2 students. This } \\
\text { shows that the effectiveness of learning in terms oflearning outcomes } \\
\text { is "very effective". }\end{array}$ \\
\hline
\end{tabular}

Copyright (C) 2018 UJES. All rights reserved.

\section{PENDAHULUAN}

Pendidikan akan menghasilkan sumber daya manusia (SDM) yang memiliki pengetahuan, intelektual dan teknologi. Ini merupakan aset untuk meningkatkan daya saing. Peningkatan kualitas pendidikan, peran dosen sangat menentukan dalam menyelenggarakan proses pembelajaran yang berkualitas. Proses pembelajaran dikatakan berkualitas bila dalam proses pembelajaran tersebut mahasiswa dapat mencapai hasil belajar yang optimal. Keberhasilan dosen dalam melaksanakan kegiatan pembelajaran akan tercermin dari hasil belajar yang dicapai mahasiswa. Pembelajaran Keriting dan Cat Rambut merupakan salah satu mata kuliah wajib pada Jurusan Tata Rias dan Kecantikan Universitas Negeri Padang. Mata kuliah Keriting dan Cat Rambut ini diikuti mahasiswa semester 4 dengan bobot 3 SKS terdiri dari 1 teori dan 2 praktek. Mata kuliah ini merupakan mata kuliah yang memberi pengetahuan dan keterampilan tentang Keriting dan Cat Rambut. 
Pembelajaran Keriting dan Cat Rambut khususnya selama ini, dosen menggunakan media pembelajaran yaitu white board, buku paket, LCD dan joobshet. Namun media yang digunakan dosen belum mampu memaksimalkan proses pembelajaran di kelas dan meningkatkan hasil belajar. Mahasiswa masih kesulitan dalam memahami konsep dasar keriting desain, alat, bahan, kosmetik keriting melakukan penggulungan rambut untuk keriting desain, melakukan pengeritingan rambut desain sesuai tekniknya, dan mengaplikasikannya. Berdasarkan pengamatan peneliti saat mengampu mata kuliah Keriting dan Cat Rambut semester Januari-Juni 2016, materi konsep dasar keriting desain dan teknik keriting desain sulit untuk dipahami dan diaplikasikan. Mahasiswa kurang dapat memahami konsep dasar keriting desain dan teknik penggulungan yang tepat sehingga hasil pengeritingan kurang maksimal. Dalam melakukan keriting desain, mahasiswa harus mampu memahami konsep dasar keriting desain, teknik keriting desain yang tepat. Selain itu, mahasiswa juga harus berlatih baik di kelas maupun di rumah agar terampil dalam melakukan keriting desain. Maka diperlukan media pembelajaran yang tepat dan menarik untuk membantu mahasiswa belajar.

Kesulitan mahasiswa memahami materi pada mata kuliah Keriting dan Cat Rambut khususnya keriting desain berdampak pada hasil belajar mahasiswa di mana nilai mahasiswa cenderung rendah. Hal ini dapat dilihat dari perolehan hasil praktek mahasiswa pada mata kuliah Keriting Rambut materi keriting desain, melakukan penggulungan rambut keriting desain seperti pada Tabel 1.

Tabel 1. Nilai Praktik Mata Kuliah Keriting dan Cat Rambut Semester Januari-Juni 2016

\begin{tabular}{|c|c|c|c|c|}
\hline \multirow{2}{*}{ No } & Materi & Nilai & Jml mhs & Persentase \\
\hline \multirow{2}{*}{} & Keriting desain & 75 & 10 & $67 \%$ \\
\cline { 3 - 5 } & & $\geq 75$ & 5 & $33 \%$ \\
\hline & 15 orang & $100 \%$ & \multicolumn{2}{|}{} \\
\cline { 2 - 5 } & &
\end{tabular}

Sumber: Arsip nilai dosen jurusan Tata Rias dan Kecantikan

Berdasarkan tabel diatas terlihat bahwa nilai praktek mahasiswa 10 orang yang memperoleh nilai dibawah 75 dan 5 orang mahasiswa yang memperoleh nilai 75 ke atas, peneliti berminat untuk meneliti tentang merancang media pembelajaran multimedia interaktif menggunakan adobe flash CS3 dan camtasia dan berbentuk CD Interaktif. Media pembelajaran ini digunakan untuk pembelajaran Keriting dan Cat Rambut khususnya materi keriting desain pada mahasiswa jurusan tata rias dan kecantikan. Peneliti tertarik untuk meneliti dengan judul" Pengembangan Media Pembelajaran Berbasis Multimedia Interaktif Pada Mata Kuliah Keriting dan Cat Rambut mahasiswa Jurusan Tata Rias dan Kecantikan FPP Universitas Negeri Padang".

\section{METODE PENELITIAN}

\section{Model Pengembangan}

Model pengembangan multimedia interaktif ini menggunakan model IDI (Instruksional Development Institute). Model IDI menetapkan prinsip-prinsip pendekatan sistem yang meliputi tiga tahap yaitu define, develop, dan evaluate (Grabowski, 2003:3). Tahap pertama yaitu tahap define (penentuan) yang berisikan langkah-langkah analisis latar belakang dan identifikasi masalah. Tahap kedua, tahap develop (pengembangan) yang berisikan penyusunan bentuk awal (prototipe) produk dan validasi produk. Sedangkan tahap ketiga yaitu tahap 
evaluate (penilaian) yang berisikan langkah-langkah uji coba dan analisis hasil uji coba.

\section{Prosedur Pengembangan}

Dalam penelitian pengembangan diperlukan design penelitian. Multimedia interaktif dikembangkan dengan menggunakan model IDI, yang terdiri dari tahap penentuan (define), pengembangan (develop), dan evaluasi (evaluate). Secara garis besar pengembangan ini dapat dilihat dari Gambar 1.

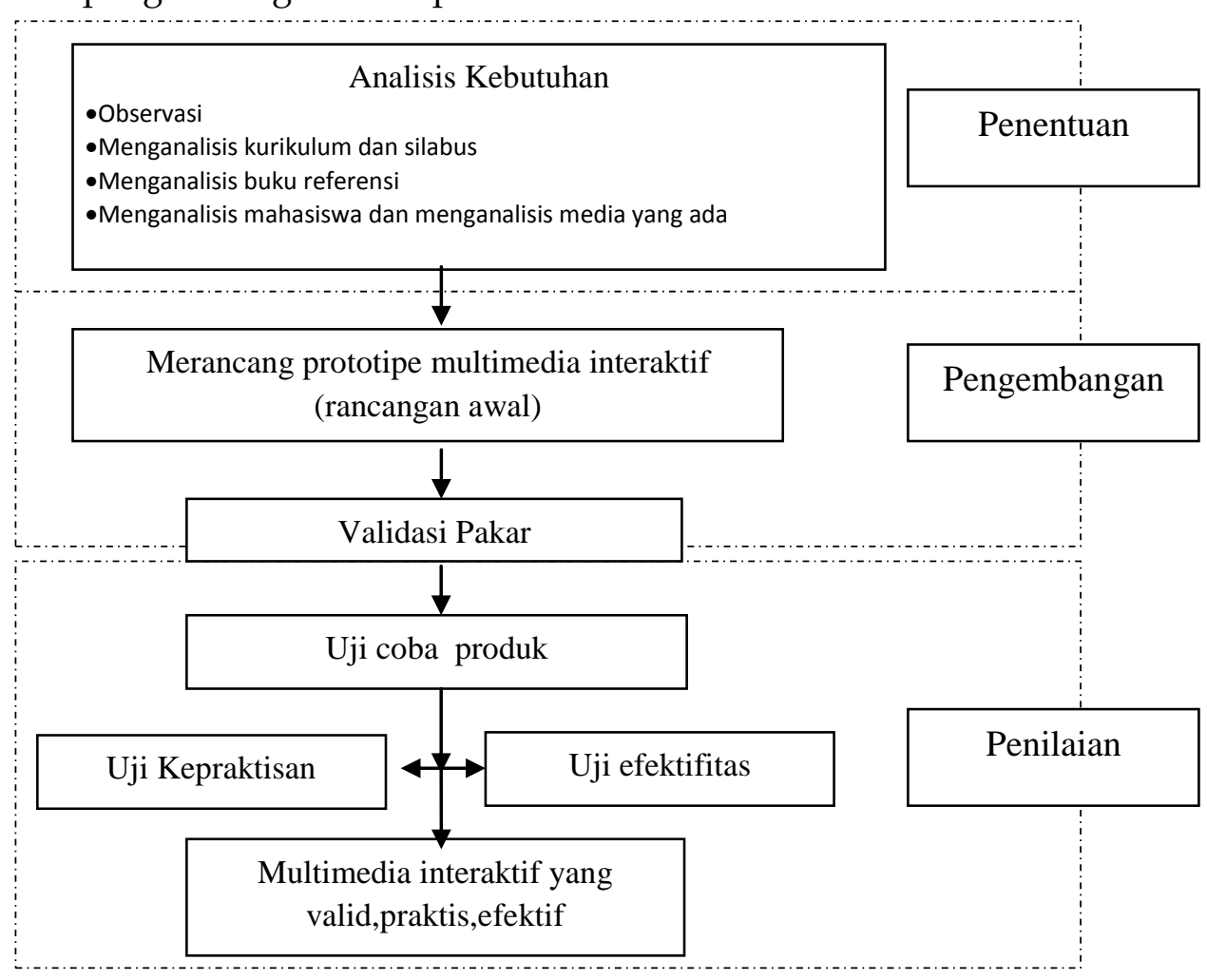

Gambar 1. Desain Pengembangan Multimedia Interaktif

\section{Subjek Penelitian}

Subjek penelitian dalam pengembangan multimedia interaktif ini adalah mahasiswa seksi 201710780017 dan dosen mata kuliah keriting dan cat rambut Jurusan Tata Rias dan Kecantikan FPP Universitas Negeri Padang.

\section{Teknik Analisis Data}

\section{Analisis Validitas}

Tabel 2. Kategori Validitas Media Pembelajaran

\begin{tabular}{ccc}
\hline No & Tingkat Pencapaian (\%) & Kategori \\
\hline 1 & $81-100$ & Sangat valid \\
2 & $61-80$ & Valid \\
3 & $41-60$ & Cukup valid \\
4 & $21-40$ & Kurang valid \\
5 & $0-20$ & Tidak valid \\
\hline
\end{tabular}

Sumber: Dimodifikasi dari Riduwan (2010:89) 


\section{Analisis Praktikalitas}

Tabel 3. Kategori Praktikalitas Media Pembelajaran

\begin{tabular}{ccc}
\hline No & Tingkat Pencapaian (\%) & Kategori \\
\hline 1 & $81-100$ & Sangat Praktis \\
2 & $61-80$ & Praktis \\
3 & $41-60$ & Cukup Praktis \\
4 & $21-40$ & Kurang Praktis \\
5 & $0-20$ & Tidak Praktis \\
\hline
\end{tabular}

Sumber: Dimodifikasi dari Riduwan (2010:89)

\section{Analisis Efektifitas}

Tabel 4. Taraf Pencapaian hasil belajar

\begin{tabular}{|c|c|c|}
\hline No & Tingkat Pencapaian (\%) & Kategori \\
\hline 1 & $81-100$ & Baik Sekali \\
2 & $61-80$ & Baik \\
3 & $41-60$ & Cukup \\
4 & $21-40$ & Kurang \\
5 & $0-20$ & Sangat Kurang \\
\hline
\end{tabular}

Sumber: Dimodifikasi dari Riduwan (2010:89)

HASIL DAN PEMBAHASAN

Multimedia interaktif dikembangkan melalui beberapa tahap antara lain:

1. Tahap Penentuan (Define)

a. Analisis Silabus

Menurut silabus yang dikeluarkan oleh dosen pengampu mata kuliah. Learning Outcomes (Capaian Pembelajaran) adalah Mampu melakukan penggulungan rambut desain sesuai prosedur dan keselamatan kerja dan Mampu melakukan pengeritingan rambut desain sesuai prosedur dan keselamatan kerja.

b. Analisis Mahasiswa

Analisis mahasiswa juga menjadi pertimbangan penting dalam mengembangkan multimedia interaktif. Analisis mahasiswa menyangkut kepada kemampuan mahasiswa terhadap penguasaan dalam penggunaan komputer dan karakteristik mahasiswa.

c. Analisis Media

Perangkat komputer yang ada pada saat sekarang ini memiliki beragam jenis dan merk. Guna mengoptimalkan pemakaian multimedia interaktif ini maka perangkat komputer yang digunakan .

d. Analisis konsep

Analisis konsep bertujuan untuk menentukan isi dan materi pelajaran yang dibutuhkan dalam pengembangan multimedia interaktif ini, peneliti menyusun konsep-konsep utama yang akan dikembangkan secara sistematis dan mengidentifikasi konsep-konsep pendukung yang relevan dan berkaitan dengan mata kuliah keriting dan cat rambut. 


\section{Tahap Pengembangan (Develop)}

Pada tahap ini, peneliti merancang multimedia interaktif melalui beberapa tahap, antara lain:

\section{a. Perancangan Prototipe Multimedia Interaktif}

Pada tahap ini dilakukan langkah-langkah sebagai berikut:

1) Penyusunan Kerangka dalam Multimedia Interaktif

Penyusunan kerangka dalam multimedia interaktif ini brupa desain tampilan multimedia interaktif yang meliputi bagian pembuka (intro), Bagian inti (isi) dan bagian penutup. Kerangka dalam multimedia interaktif ini antara lain:

a) Bagian intro (pembuka).

b) Menu utama terdiri dari menu silabus, menu materi, menu kuis, menu about, menu keluar

- Silabus, berisi tentang informasi multimedia interaktif seperti silabus

- Materi, berisikan tentang deskripsi, materi dan viseo .

- Kuis, berisis form kuis, soal dan hasil kuis.

- About, berisi halaman about atau profil peneliti dosen pemula

- Menu keluar

\section{b. Perancangan Multimedia Interaktif}

Hasil perancangan konten dapat dilihat pada gambar di bawah ini:

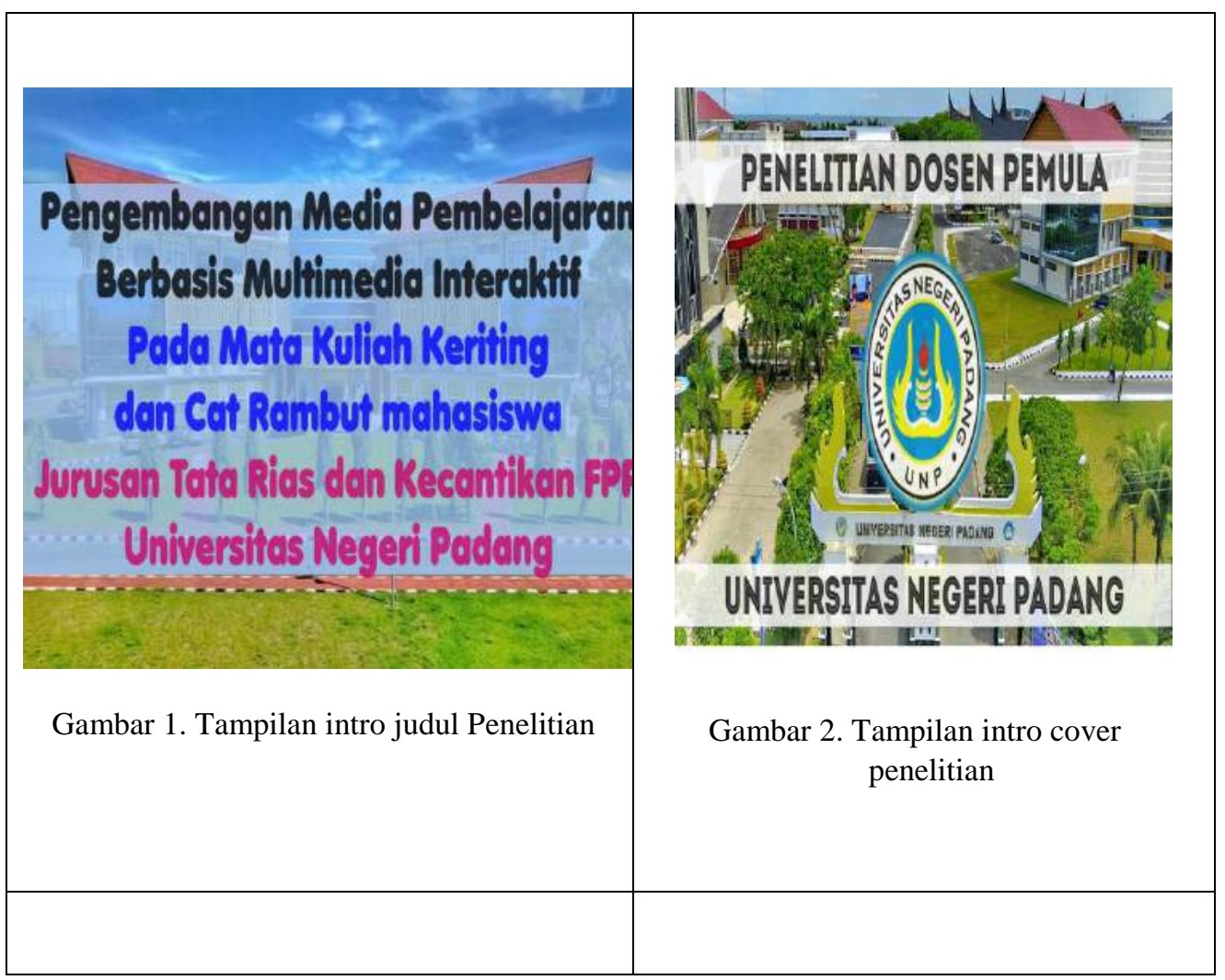




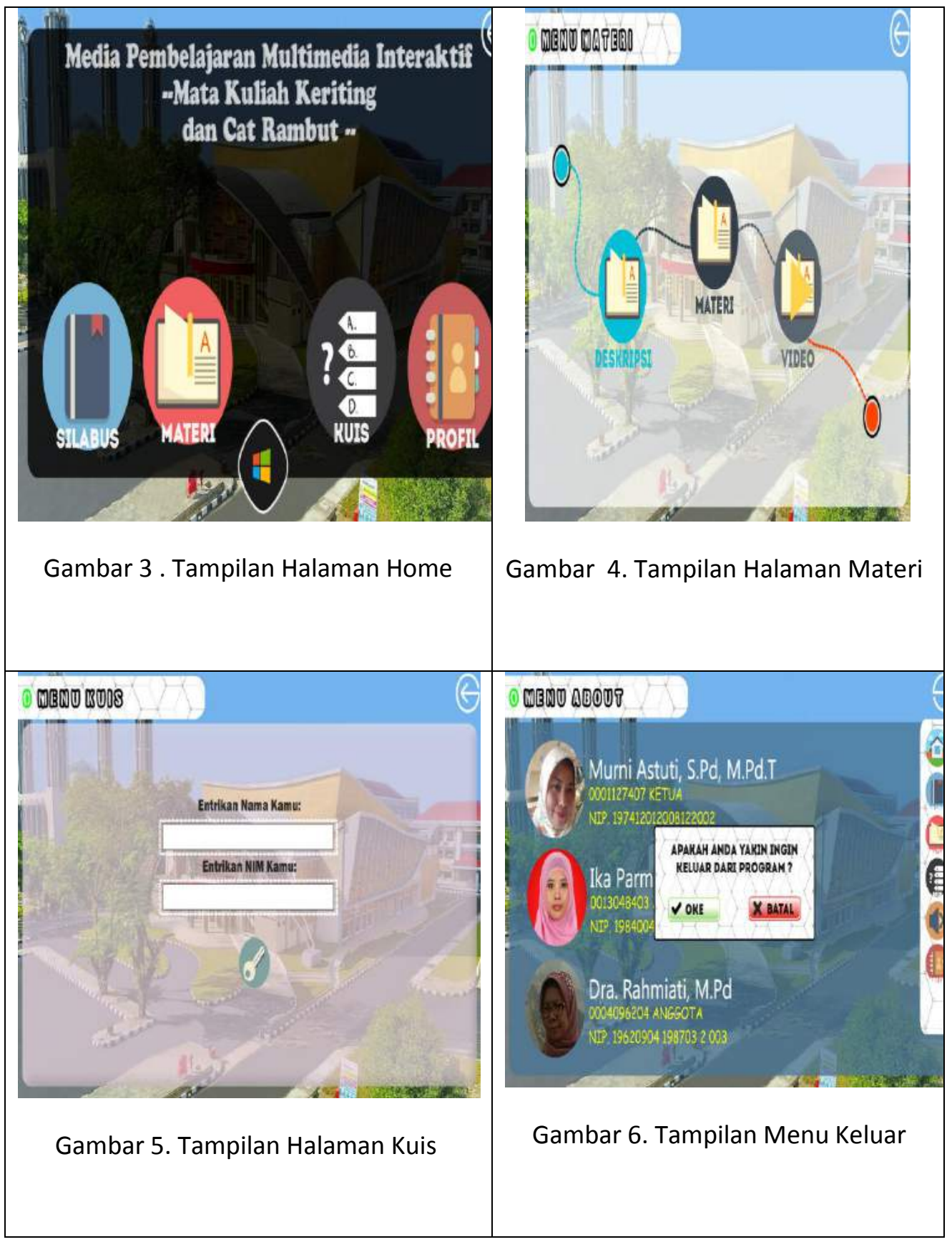

\section{Tahap Penilaian (Evaluate)}

\section{a. Analisis Uji Praktikalitas Multimedia Interaktif}

Data praktikalitas media diambil melalui uji coba terbatas yang dilakukan di Jurusan Tata Rias dan Kecantikan FPP Universitas Negeri Padang pada kelas kode seksi 201710780017 yang ditentukan secara acak dari 2 kelas yang ada. Uji coba ini bertujuan untuk melihat keterlaksanaan pembelajaran dengan menggunakan multimedia interaktif. Dalam proses uji coba, peneliti dabantu oleh dua orang dosen mata kuliah keriting dan cat rambut Jurusan Tata Rias dan Kecantikan FPP Universitas Negeri Padang yaitu Dra. Hayatunnufus, M.Pd dan Tyas Asih Surya M,S.Pd, M.Pd.T.

Penilaian terhadap praktikalitas media diperoleh dari angket yang diisi oleh dosen/praktisi dan hasil yang diperoleh dapat dilihat pada tabel 13. Praktisi 
pertama menilai multimedia interaktif yang dikembangkan tersebut berada pada kategori Sangat Praktis dengan persentase rata-rata 97,5\% sedangkan praktisi kedua memberikan penilaian Sangat Praktis dengan persentase ratarata 83,75 .

Selain penilaian dari dosen/praktisi, kepraktisan multimedia interaktif juga dinilai berdasarkan tanggapan mahasiswa melalui angket. Pada aspek kemudahan media diperoleh persentase rata-rata 92,5\%, aspek Efektifitas waktu 90\%, dan aspek Penginterpretasikan Media 85\%, dan Ekivalensi 95\% dengan persentase rata-rata keseluruhan yaitu 90,63\%. Sehingga dapat disimpulkan bahwa multimedia interaktif yang dikembangkan dikategorikan Sangat Praktis

\section{b. Analisis Uji Efektifitas Multimedia Interaktif}

Untuk melihat efektifitas pengembangan Multimedia interaktif pada mata kuliah keriting dan cat rambut Jurusan Tata Rias dan Kecantikan dilakukan dengan melakukan tes hasil belajar yang dilaksanakan pada akhir pembelajaran. Hasil tes ini dapat dilihat berdasarkan data yang diperoleh dari hasi uji efektifitas Multimedia interaktif maka peneliti dapat menjelaskan bahwa mahasiswa yang tuntas (Persentase nilai $\geq 85$ s.d 100 Nilai Mutu A Angka Mutu 4) sebanyak 15 orang (75\%) dan yang belum mencapai (Persentase nilai $\geq 85$ s.d 100 Nilai Mutu A Angka Mutu 4) adalah sebanyak 5 orang $(25 \%)$, sehingga nilai $\geq 85$ s.d 100 yang telah ditetapkan A adalah $\mathbf{8 6 , 9 \%}$ efektifitas multimedia interaktif tersebut dikategorikan "Sangat efektif".

\section{SIMPULAN}

1. Validasi media pada mata kuliah Keriting dan Cat Rambut telah dinilai oleh validator dari berbagai kajian dengan kriteria Materi dan bentuk/desain media dengan kategori "sangat valid".

2. Kepraktisan media dalam pembelajaran dapat dilihat dari keterlaksanaan penggunaan media pembelajaran secara keseluruhan dengan baik. Ini terlihat dari hasil respon dosen/praktisi yang memperoleh persentase rata-rata 90,63 \% , dan hasil respon mahasiswa yang memperoleh persentase rata-rata 88,17\%. Hal ini menunjukkan media pembelajaran yang dikembangkan termasuk pada kategori "sangat praktis".

3. Efektivitas media yang dikembangkan terhadap mahasiswa dilihat dari Hasil belajar mahasiswa setelah pembelajaran dengan menggunakan Multimedia Interaktif. Jumlah mahasiswa yang mencapai nilai tuntas sebanyak $75 \%$, dengan nilai rata-rata mahasiswa 86,2 . Hal ini menunjukan bahwa efektifitas pembelajaran dari segi hasil belajar adalah "sangat efektif".

\section{DAFTAR PUSTAKA}

Akker, Van Den. Branch, R.M. Gustafson, K. Nieveen, N. dan Plomp, T. (Eds.). 1999. Design Approach And Tools In Education and Training. Dordrecht: Kluwer Academic Publishers

Arikunto, Suharsimi. 2012. Dasar-Dasar Evaluasi Pendidikan Edisi 2. Jakarta: Bumi Aksara.

Arsyad, Azhar. 2013. Media Pembelajaran. Jakarta: PT Raja Grafindo Persada 
Astuti, Murni. 2013. Pengembangan Media Pembelajaran Menggunakan Video Mata Kuliah Dasar Tata Rias Program Studi Tata Rias dan Kecantikan FT UNP. Thesis tidak diterbitkan. Padang: Program Pasca Sarjana FT UNP Padang

Grabowski, Sarah. 2003. Teaching \& Media: A Systematic Approach. The Gerlach \& Ely Model, (online), EDIT 6180, (http://sarah.lodick.com/edit/edit6180/gerlach_ely.pdf, diakses 14 Agustus 2017)

Riduwan. 2010. Belajar Mudah Penelitian Untuk Guru-Karyawan dan Peneliti Pemula. Bandung: Alfabeta.

Rusman. 2012. Belajar dan Pembelajaran Berbasin Komputer: Mengembangkan Profesional Guru Abad 21. Bandung: Alfabeta. 